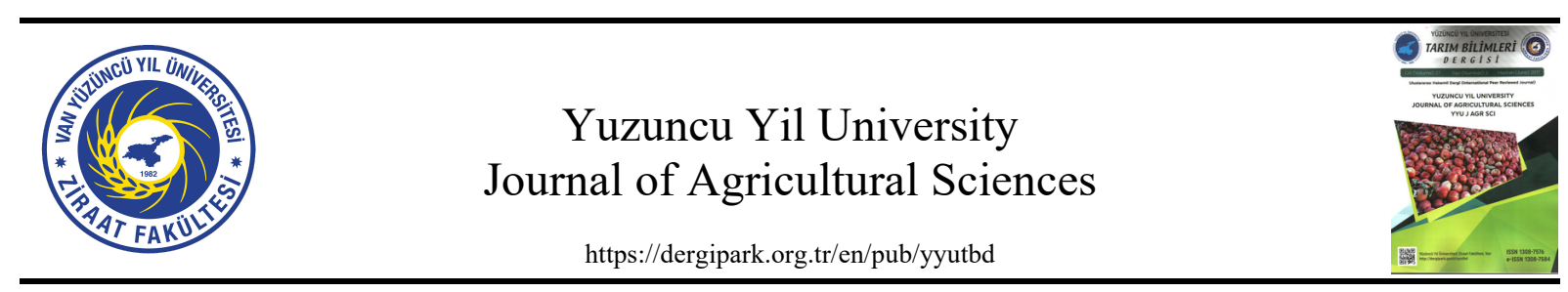

Research Article

\title{
In Vitro Propagation of Some Mahaleb Genotypes as Candidate Rootstock for Sweet Cherries
}

\author{
Erol AYDIN*1, Tarık YARILGAÇ ${ }^{2}$
}

${ }^{1}$ Karadeniz Tarımsal Araştırma Enstitüsü Bahçe Bitkileri Bölümü, Samsun, Türkiye

${ }^{2}$ Yükseköğretim Kurulu Denetleme Kurulu Başkanlığı, 06800, Ankara, Türkiye

${ }^{1}$ https://orcid.org/ 0000-0002-2710-4075 ${ }^{2}$ https://orcid.org/ 0000-0003-2097-7161

*Corresponding Author e-mail: aydin.erol@tarimorman.gov.tr

\section{Article Info}

Received: 09.03.2021

Accepted: 03.10.2021

Online Published: 15.12.2021

DOI: $10.29133 /$ yyutbd.892027

\section{Keywords}

Micropropagation, MS,

Prunus avium,

Rooting,

Rootstock.

\begin{abstract}
In this study, where carried out in 3 mahaleb genotypes and SL 64 (St. Lucie 64) rootstocks which can be rootstock candidate for cherry were investigated in order to determine the multiplication performance of in vitro conditions, shoot tips were used as explant of with mahaleb genotypes and SL 64 rootstocks. Surface sterilization was applied to the explants in the initial stage $0.5 \mathrm{mg} \mathrm{l}^{-1}$ BAP (6Benzylaminopurine) $+0.1 \mathrm{mg} \mathrm{l}^{-1} \mathrm{GA}_{3}$ (Gibberellic acid) $+0.1 \mathrm{mg} \mathrm{l}^{-1}$ IBA (Indole-3butyric acid) was cultured in MS (Murashige and Skoog) medium. The study was carried out to determine the effect of different BAP $\left(0,0.5\right.$ and $\left.1 \mathrm{mg} \mathrm{l}^{-1}\right)$ doses during the shoot multiplication stage, the number of shoots was 1.97-2.55 in mahaleb genotypes. While the number of shoots increased with increasing BAP dose, the maximum number of shoots was obtained from $1 \mathrm{mg} \mathrm{l}^{-1}$ BAP dose. In the rooting stage, $0,0.5,1$ and 2 IBA was added to $1 / 2 \mathrm{MS}$ medium. The effect of different doses of IBA $\left(0,0.5,1,2 \mathrm{mg} \mathrm{l}^{-1}\right)$ in rooting medium was investigated. While the best results in terms of callus ratio, rooting rate and root length were obtained from $2 \mathrm{mg} \mathrm{l}^{-1}$ IBA dose, the best results in terms of rooted plant length and number of leaves were obtained from $1 \mathrm{mg} \mathrm{l}^{-1}$ IBA dose.
\end{abstract}

\section{Kiraz İçin Anaç Adayı Bazı Mahlep Genotiplerinin İn vitro Çoğaltımı}

\section{Makale Bilgileri}

Geliş: 09.03.2021

Kabul: 03.10.2021

Online Yayınlanma: 15.12.2021

DOI: 10.29133 /yyutbd.892027

\section{Anahtar Kelimeler}

Mikroçoğaltım, MS,

Prunus avium, Köklenme, Anaç.
Öz: Kiraz için anaç adayı olabilecek 3 adet mahlep genotipi ve SL 64 (St. Lucie 64) anacınınım in vitro şartlarında çoğaltılabilme olanakları araştırıldığı bu çalışmada eksplant olarak mahlep genotipleri ve SL 64 anacının sürgün uçları kullanılmıştır. Eksplantlar yüzey sterilizasyonu yapılarak başlangıç aşamasında $0.5 \mathrm{mg} / \mathrm{l} \mathrm{BAP}$ (6-Benzilaminopurin) $+0.1 \mathrm{mg} \mathrm{l}^{-1} \mathrm{GA}_{3}$ (Gibberellic acid) +0.1 $\mathrm{mg} / \mathrm{l}$ IBA (İndole-3-butyric acid) içeren MS (Murashige ve Skoog) besi ortamında kültüre alınmıştır. Çoğaltma ortamında farklı BAP $(0,0.5$ ve $1 \mathrm{mg} / \mathrm{l})$ dozlarının etkisini belirlemek için yapılan çalışmada sürgün sayısı 1.97-2.55 adet arasında değişmiştir. BAP dozunun artması ile sürgün sayısının arttığı belirlenirken, en fazla sürgün sayısı $1 \mathrm{mg} / \mathrm{l}$ BAP dozundan elde edilmiştir. Köklendirme aşamasında ise farklı IBA dozlarının $(0,0.5,1$ ve $2 \mathrm{mg} / \mathrm{l})$ etkisi araştırılmıştır. Kallus oranı, köklenme oranı ve kök uzunluğu bakımından en iyi sonuçlar $2 \mathrm{mg} / \mathrm{l}$ IBA dozundan elde edilirken, köklü bitkinin uzunluğu ve yaprak sayısı bakımından ise en iyi sonuçlar $1 \mathrm{mg} / \mathrm{l}$ IBA dozundan elde edilmiştir.

\footnotetext{
** This article produced from the PhD thesis of Erol AYDIN.
} 


\section{Introduction}

The Rosales team, which includes sweet cherry, cherry, and mahaleb, many temperate climate fruit species, is in the Rosaceae family, the Prunoideae subfamily Prunus (Özçağıran et al., 2005).

Mahleb's homeland is Europe and West Asia. Prunus mahaleb has spread naturally in a wide area of the World. Southern Europe, mountainous regions of Central Europe naturally spread over a wide area extending to France, South Germany, North Asia, the Caucasus, and Turkestan (Meraler, 2010).

Mahaleb is used as a rootstock for sweet cherry and cherry cultivation. Mahaleb rootstocks are smaller trees than bird cherry. It is not a suitable rootstock for heavy textured soils with high groundwater. On lands with low irrigation possibilities, drought, and salinity problems, mahaleb rootstocks are more suitable for growing (Özyurt and Akça, 2017).

The rootstocks used in fruit cultivation do not show homogenous development due to their genetic differences and they have late yield. Therefore, the use of certified clonal rootstocks, whose growth force is homogeneous and free from diseases and pests, is becoming widespread in modern fruit growing.

Depending on the growing power of rootstocks, garden plant costs and operating costs change in the coming years as the number of saplings to be planted per unit area changes. Inbreeding with dwarf and semi-dwarf cherry rootstocks, more and earlier yields can be obtained from the unit area (Whiting et al., 2005).

Our country, which has a very important position in the world cherry production, still maintains its importance in terms of being a source of genes for these fruit species. Among the stone fruits, plants belonging to the culture and wild species in the cherry-cherry group can be found in almost all regions of our country. Sour cherry and cherry cultivation in Turkey, mahaleb ( $P$. mahaleb), cherry ( $P$. avium), and sour cherry ( $P$. cerasus) seedlings are widely used. The production of cherry saplings in Turkey, $40 \%$ cherry rootstock, $30 \%$ mahaleb rootstocks, $30 \%$ Gisela 5, Gisela 6, and SL 64 clone rootstocks are used (Ercişli et al., 2006).

Turkey has rich potential in terms of cherry and sour cherry genetic resources. More concrete results can be obtained by ensuring integration in the cherry rootstock breeding studies and carrying out extensive studies. On the other hand, we do not have domestic cherry and cherry clone rootstock in cherry-cherry production in our country's fruit growing, as in other species (Koç, 2009).

In addition to the traditional methods such as dipping and cutting, micropropagation methods, which provide a large number of materials in a short time, have gained importance in the production of clone rootstocks.

In addition to use in breeding studies, in vitro techniques have found increasing use in recent years for commercial production purposes. In particular, propagation of clonal Prunus rootstocks with tissue culture has become a major commercial sector. To rootstock production, it will be possible to obtain healthy plant material in a short time with the determination of tissue culture and propagation protocols of the cultivars with high production potential and replication studies to be performed. Micropropagation in vitro conditions is not affected by environmental conditions. In terms of labor and time spent in micropropagation studies carried out in large quantities, a profit is obtained (Aka-Kaçar et al., 2001).

In the propagation of cherry and cherry with tissue culture, MS (Murashige Skoog) is generally used by modifying the macro and microelements of the nutrient medium, and in some cases, the MS medium. One of the modifications is to increase the amount of iron against yellowing symptoms (Skirvin, 1984). As a vitamin in the nutrient medium, 10 different vitamin mixes and MS vitamins are used (Skirvin and Chu, 1979). As an energy source, 20-30 $\mathrm{g} \mathrm{l}^{-1}$ concentration of sucrose is added, in some cases, higher concentrations are used. In Prunus species, the solid medium is preferred more than the liquid medium and 6-8 $\mathrm{g} \mathrm{l}^{-1}$ agar is a suitable dose. Culture concentrations with plant growth regulators used vary according to the stage and plant type (Borkowska and Szczerba, 1991; Morini et al.,1992).

Since genotype is also effective in achieving success in micropropagation studies, it is important to develop a separate protocol for each clone rootstock. In this regard, in order to increase the multiplication coefficients of cherry rootstocks, new growth regulator combinations should be tried (Güçlü et al., 2010). 
As a result of the evaluation of genotypes collected from the natural flora of the Black Sea Region according to the characteristics that define Prunus rootstocks in UPOV criteria, this study was carried out in order to determine the micropropagation performance of mahaleb genotypes, which have the potential to be rootstock for cherries.

\section{Materials and Methods}

The study was carried out between 2015-2016 in the tissue culture laboratory at Çukurova University Biotechnology Research and Application Center. According to the results of the project numbered TOVAG 106 O 031 in the genetic resources parcel of the Black Sea Agricultural Research Institute, 3 Prunus mahaleb genotypes and SL 64 rootstocks, which may be rootstock candidates, are the materials of the study (Bilginer et al., 2009). Selection code and location information of mahaleb genotypes used as material are given in Table 1 .

Table 1. Genotypes selection code and location information

\begin{tabular}{|c|c|c|c|}
\hline City & Town & Village & Selection code \\
\hline \multicolumn{4}{|c|}{ Mahaleb genotypes } \\
\hline Giresun & Şebinkarahisar & Merkez & $28 \mathrm{M} 005$ \\
\hline Ordu & Mesudiye & Ekşere & $52 \mathrm{M} 003$ \\
\hline Samsun & Vezirköprü & Merkez & $55 \mathrm{M} 005$ \\
\hline
\end{tabular}

In the research, 5 year-old mahaleb genotypes and the shoot tips and nodal buds of the SL 64 rootstock were used for in vitro propagation. In order to prevent infection, trees that were sampled 15 days before sampling were regularly sprayed with benomyl active fungicide and streptomycin sulfate. The annual shoots were taken from the Black Sea Agricultural Research Institute land and wrapped in damp paper towels and transported to the laboratory environment in the vehicle type refrigerator. Shoot tip and side bud explants were prepared, and materials were washed under tap water for 30 minutes in order to remove substances such as dust and dirt. The explants were taken into a sterile cabin for 3 minutes in $70 \%$ ethyl alcohol and then passed through sterile pure water 3 times. The materials were then sterilized for 10 minutes at a $10 \%$ concentration of commercial sodium hypochlorite (NaOCL) containing 1-2 drops of tween 20. The explants were shaken 3 times in sterile distilled water and washed sterile distilled water. In the initiation of explants, MS essential nutrient medium containing macro and micronutrients and vitamins was used and $30 \mathrm{~g} \mathrm{l}^{-1}$ sucrose and $7 \mathrm{~g}^{-1}$ agar were added to the medium. As the starting medium $\mathrm{MS}+0.1 \mathrm{mg}^{-1} \mathrm{GA}_{3}+0.1 \mathrm{mg} \mathrm{l}^{-1} \mathrm{IBA}+0.5 \mathrm{mg} \mathrm{l}^{-1}$ BAP, shoot multiplication MS $+0.1 \mathrm{mg} \mathrm{l}^{-1} \mathrm{GA}_{3}+0.1 \mathrm{mg} \mathrm{l}^{-1} \mathrm{IBA}, 0 \mathrm{mg} \mathrm{l}^{-1} \mathrm{BAP}, 0.5 \mathrm{mg} \mathrm{l}^{-1} \mathrm{BAP}, 1 \mathrm{mg}^{-1} \mathrm{BAP}$ and rooting medium $1 / 2$ MS, $0.0 \mathrm{mg} \mathrm{l}^{-1} \mathrm{IBA}, 0.5 \mathrm{mg} \mathrm{l}^{-1} \mathrm{IBA}, 1.0 \mathrm{mg} \mathrm{l}^{-1} \mathrm{IBA}$ and $2.0 \mathrm{mg} \mathrm{l}^{-1} \mathrm{IBA}$ were added in the rooting medium. Before adding agar to the prepared media, the $\mathrm{pH}$ of the medium was adjusted to 5.7 and the nutrient media was poured as much as $40 \mathrm{ml}$ into $175 \mathrm{ml}$ jars. All components of the media were autoclaved together autoclaved under $121^{\circ} \mathrm{C}$ temperature and $1.2 \mathrm{~kg} / \mathrm{cm}^{2}$ pressure for 20 minutes.

The autoclaved media were placed in the sterile cabinet and the media were allowed to cool until they reached room temperature. The explants cultured to the medium in the jar were placed in a climate room at $25 \pm 1{ }^{\circ} \mathrm{C}, 2500$ lux illumination, 16 hours light, and 8 hours dark darkness. In the growing conditions in this way, the optimal conditions for the development of cultures are provided. Subculture was carried out by transferring the explants taken to the culture to fresh media in the sterile cabin with an interval of 4 weeks. It was transferred to the rooting medium after the fourth subculture. The following characters have been determined in mahaleb genotypes and SL 64 rootstocks.

Infected Explant Rate (\%): Considering the development of the cultures, at the end of the 28-day culture, the ratio of the number of infected cultures to all cultures was expressed as a percentage of infected explant (Yıldırım, 2006).

Shoot Number (pieces): The shoots made up of each explant were counted during the first culturing, surprising, and micropropagation stages (Sülüşoğlu, 2002).

Callus Rate (\%): It refers to the rate of callus 30 days after the shoots taken to the rooting medium (Sülüş̧oğlu, 2002).

Rooting Rate (\%): It refers to the rate of rooting 30 days after the shoots taken to the rooting medium (Sülüşoğlu, 2002). 
Root Length (mm): It was determined by measuring the root lengths of the rooted shoots by measuring them with a digital caliper (Y1ldırım, 2006).

The Length of the Rooted Plant $(\mathrm{mm})$ : The length of the rooted plant was determined by measuring the shoot lengths with a digital caliper as a result of the rooting period (Sülüşoğlu, 2002).

Number of Leaves (number): It refers to the average number of leaves that have taken the normal shape on the shoots that continue their development as a result of rooting time (Aktürk, 2009).

All experiments in the study were set up to be 3 repetitions and 20 explants each time according to the trial parcel of random parcels. The data obtained from the experiment were analyzed in one way in ANOVA statistical package program, and the differences between the genotypes were compared with the LSD multiple comparison test

\section{Results}

The differences between the mahaleb genotypes and the infected culture rate of SL 64 rootstock were statistically significant at the level of $1 \%$ and $5 \%$. In 2015, the infected culture rate was highest in the $55 \mathrm{M} 005$ genotype (28.19\%), while the infected culture rate was the lowest $(15.80 \%)$ in the $52 \mathrm{M}$ 003 genotype. In 2016, 55 M 005 genotype ranks first with $31.54 \%$ in terms of infected culture, while 28 M 005 genotype ranks last with $17.78 \%$.

Table 2. Mahaleb genotypes and SL 64 rootstock of infected culture rates (\%)

\begin{tabular}{cccc}
\hline \multicolumn{4}{c}{ Infected culture rate $(\%)$} \\
\hline Genotype & 2015 year & 2016 year & Year average \\
\hline 28 M 005 & $23.49 \pm 1.77 \mathrm{~A}$ & $17.78 \pm 1.38 \mathrm{C}$ & $20.64 \pm 1.62 \mathrm{~B}$ \\
$52 \mathrm{M} \mathrm{003}$ & $15.80 \pm 0.65 \mathrm{~B}$ & $24.44 \pm 1.40 \mathrm{~B}$ & $20.12 \pm 2.05 \mathrm{~B}$ \\
55 M 005 & $28.19 \pm 1.49 \mathrm{~A}$ & $31.54 \pm 1.30 \mathrm{~A}$ & $29.07 \pm 1.27 \mathrm{~A}$ \\
SL 64 & $17.14 \pm 1.99 \mathrm{~B}$ & $20.00 \pm 0.77 \mathrm{C}$ & $18.57 \pm 1.15 \mathrm{~B}$ \\
CV(\%) & 12.84 & 6.85 & 11.04 \\
Genotype & $*$ & $* *$ & $* *$ \\
LSD & 5.60 & 3.34 & 2.99 \\
\hline
\end{tabular}

Different letters in the same line or column are statistically significant.

${ }^{* *}$ significant at $\mathrm{p} \leq 0.01$.

*significant at $\mathrm{p} \leq 0.05$.

CV: Coefficient of variation.

LSD: Least significant difference.

As it can be understood from Table 3 it was determined that the effect of BAP concentration on mahaleb genotypes and the number of shoots in SL 64 rootstock was statistically significant at a 1\% level. The maximum number of shoots was obtained from $1 \mathrm{mg}^{-1} \mathrm{BAP}$ dose of $52 \mathrm{M} 003$ and $55 \mathrm{M} 005$ genotypes in 2015, and $1 \mathrm{mg} \mathrm{l}^{-1} \mathrm{BAP}$ dose of $52 \mathrm{M} 003$ genotype according to 2016 and years average data. The minimum number of shoots was obtained from $0 \mathrm{mg}^{-1}$ BAP dose of mahaleb genotypes in 2015, and from $0 \mathrm{mg} \mathrm{l}^{-1,}$ BAP dose of $52 \mathrm{M} 003$ and $55 \mathrm{M} 005$ genotypes according to 2016 and years average data. In terms of the average number of shoots, the genotypes of $52 \mathrm{M} 003$ and $55 \mathrm{M} 005$ in 2015 and the $52 \mathrm{M} 003$ genotype had the highest number of shoots compared to the average of 2016 and years. According to the year order, $28 \mathrm{M} \mathrm{005,55} \mathrm{M} 005$ and SL 64 rootstocks had the minimum number of shoots. In terms of applied BAP doses, the average number of shoots was the highest in $1 \mathrm{mg} \mathrm{l}^{-1}$ BAP dose, followed by 0.5 and $0 \mathrm{mg}^{-1}$ BAP doses in decreasing order.

As can be seen from Table 4, according to the data of the first and second years of the experiment in mahaleb genotypes, SL 64 rootstocks had callus rate the highest at $2 \mathrm{mg}^{-1}$ IBA dose of SL 64 rootstocks. It was stated that the callus rate was the lowest in the $0 \mathrm{mg} \mathrm{l}^{-1}$ IBA doses of the $28 \mathrm{M}$ 005 genotype. The SL 64 rootstock ranks first in terms of average callus rate, while the $55 \mathrm{M} 005$ genotype ranks last. In terms of IBA doses applied in mahaleb genotypes, callus rate was highest in 2 $\mathrm{mg} 1^{-1}$ IBA dose, followed by 1 and $0.5 \mathrm{mg}^{-1}$ IBA doses in decreasing order. 
Table 3. Effect of BAP doses on mahaleb genotypes and SL 64 rootstock of number of shoots and LSD multiple groupings

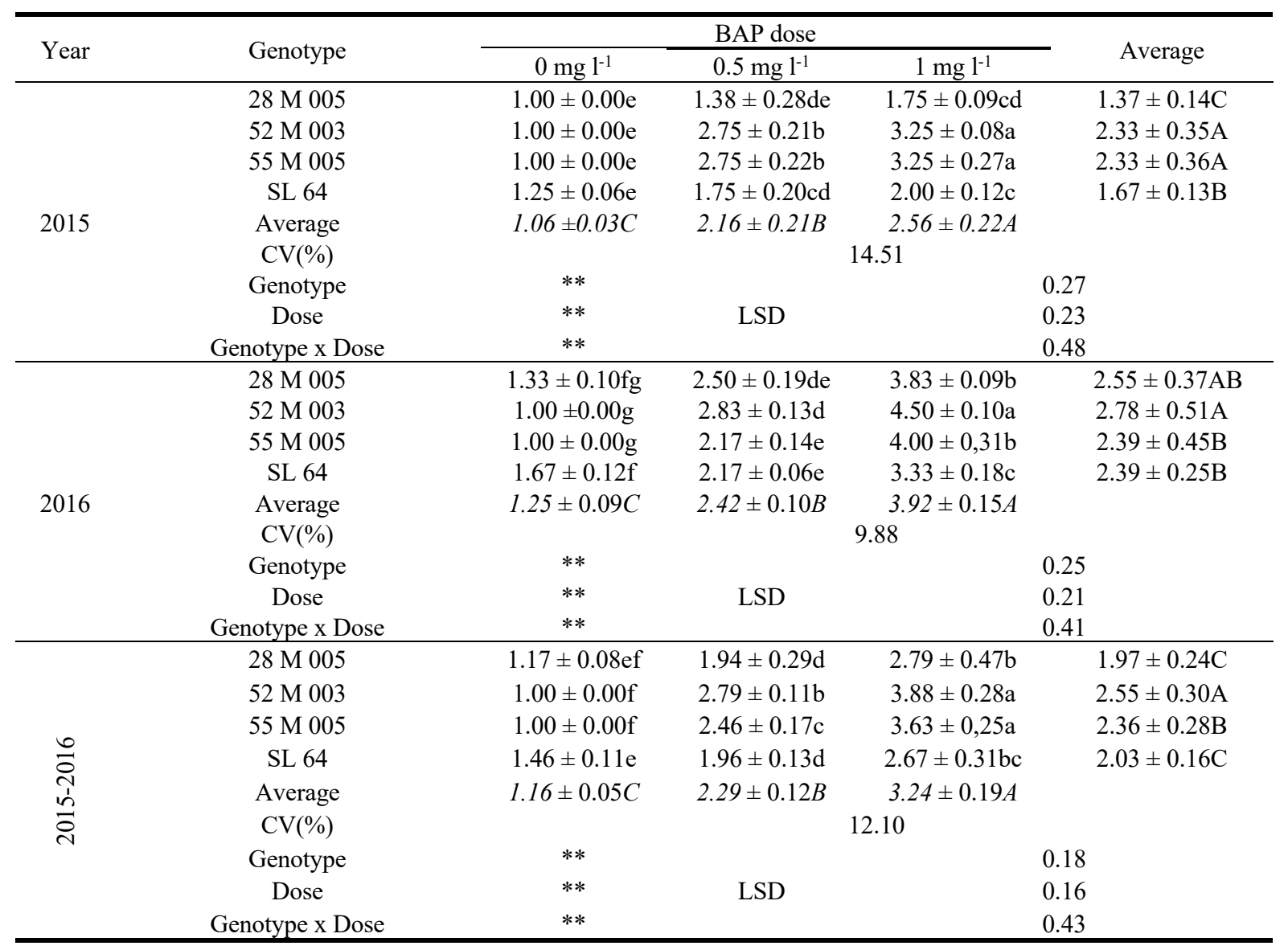

** Different letters in the same line or column are statistically significant at $p \leq 0.01$.

As stated in Table 6 root length of mahaleb genotypes was determined to be $0.5 \mathrm{mg}^{-1}$ IBA dose of $52 \mathrm{M} 003$ genotype, and the longest of $52 \mathrm{M} 003$ genotype was $2 \mathrm{mg} \mathrm{l}^{-1}$ IBA in 2016 according to the average of 2015 and years. The root length of $28 \mathrm{M} 005$ and $55 \mathrm{M} 005$ genotypes was found to be the shortest at 0 and $0.5 \mathrm{mg} \mathrm{l}^{-1}$ IBA doses. In the mahaleb genotypes, the longest root was obtained at a dose of $2 \mathrm{mg} \mathrm{l}^{-1} \mathrm{IBA}$, followed by 1 and $0.5 \mathrm{mg} \mathrm{l}^{-1}$ IBA doses, respectively. In terms of average root length, $52 \mathrm{M} 003$ genotype has the longest root, while $55 \mathrm{M} 005$ genotype has the shortest root.

When we evaluate Table 7 where rooted plant length is given in mahaleb genotypes; rooted plant length is $1 \mathrm{mg} \mathrm{l}^{-1}$ IBA dose of SL 64 rootstock in the first year. According to the data of the second year and years, it was measured at the longest dose of $1 \mathrm{mg} \mathrm{l}^{-1}$ of the $28 \mathrm{M} 005$ genotype. Rooted plant length was determined as shortest at 0 and $0.5 \mathrm{mg} \mathrm{l}^{-1} \mathrm{IBA}$ doses of $28 \mathrm{M} 005$ and $55 \mathrm{M} 005$ genotypes. In terms of average rooted plant length, SL 64 rootstock ranks first, while $55 \mathrm{M} 005$ genotype was found to be in the last row. Rooted plant length was found to be the longest at $1 \mathrm{mg}^{-1}$ IBA dose and the shortest at $0 \mathrm{mg} \mathrm{l}^{-1} \mathrm{IBA}$ dose in mahaleb genotypes.

As can be seen from Table 8, according to the data of the first year and years of the experiment in mahaleb genotypes, SL 64 rootstocks had the highest number of leaves at $0.5 \mathrm{mg} \mathrm{l}^{-1}$ IBA dose of 52 M 003 genotype in the second year. It was stated that the number of leaves was the lowest in the 0 and $0.5 \mathrm{mg} \mathrm{l}^{-1}$ IBA doses of the $28 \mathrm{M} 005$ and $55 \mathrm{M} 005$ genotypes. The $52 \mathrm{M} 003$ genotype ranks first in terms of average number of leaves, while the $55 \mathrm{M} 005$ genotype ranks last. In terms of IBA doses applied in mahaleb genotypes, the number of leaves was highest in $1 \mathrm{mg}^{-1}$ IBA dose, followed by 2 and $0.5 \mathrm{mg} \mathrm{l}^{-1}$ IBA doses in decreasing order. 
Table 4. Effect of BAP doses on mahaleb genotypes and SL 64 rootstock of callus rate and LSD multiple groupings

\begin{tabular}{|c|c|c|c|c|c|c|}
\hline \multirow{2}{*}{ Year } & \multirow{2}{*}{ Genotype } & \multicolumn{4}{|c|}{ IBA Dose } & \multirow{2}{*}{ Average } \\
\hline & & $0 \mathrm{mg} \mathrm{l}^{-1}$ & $0.5 \mathrm{mg} \mathrm{l}^{-1}$ & $1 \mathrm{mg} \mathrm{l}^{-1}$ & $2 \mathrm{mg} \mathrm{l}^{-1}$ & \\
\hline \multirow{9}{*}{2015} & $28 \mathrm{M} 005$ & $35.00 \pm 2.9$ & $54.00 \pm 4.0$ & $70.67 \pm 3.5$ & $85.33 \pm 4.9$ & $61.25 \pm 5.9 \mathrm{~B}$ \\
\hline & $52 \mathrm{M} 003$ & $54.00 \pm 2.1$ & $66.33 \pm 2.7$ & $80.00 \pm 12.2$ & $93.00 \pm 4.0$ & $73.33 \pm 5.2 \mathrm{~A}$ \\
\hline & $55 \mathrm{M} 005$ & $35.00 \pm 2.9$ & $40.00 \pm 2.9$ & $75.00 \pm 2.9$ & $68.33 \pm 2.4$ & $54.58 \pm 5.4 \mathrm{~B}$ \\
\hline & SL 64 & $66.33 \pm 5.5$ & $61.67 \pm 6.1$ & $88.00 \pm 6.1$ & $93.33 \pm 3.5$ & $77.33 \pm 4.7 \mathrm{~A}$ \\
\hline & Average & $47.58 \pm 4.3 C$ & $55.50 \pm 3.5 B$ & $78.42 \pm 3.6 A$ & $85.00 \pm 3.5 \mathrm{~A}$ & \\
\hline & $\mathrm{CV}(\%)$ & & & 12.69 & & \\
\hline & Genotype & $* *$ & & & 7.03 & \\
\hline & Dose & $* *$ & LSD & & 7.04 & \\
\hline & Genotype x Dose & ns & & & - & \\
\hline \multirow{9}{*}{2016} & $28 \mathrm{M} 005$ & $30.33 \pm 2.6 j$ & $68.67 \pm 4.7 \mathrm{dg}$ & $67.67 \pm 6.2 \mathrm{dg}$ & $86.67 \pm 8.8 \mathrm{abc}$ & $63.33 \pm 6.7 \mathrm{~B}$ \\
\hline & $52 \mathrm{M} 003$ & $55.33 \pm 2.9 \mathrm{gh}$ & $63.33 \pm 2.4 \mathrm{fg}$ & $90.67 \pm 4.8 \mathrm{ab}$ & $93.67 \pm 3.8 \mathrm{a}$ & $75.75 \pm 5.3 \mathrm{~A}$ \\
\hline & $55 \mathrm{M} 005$ & $35.00 \pm 2.91 \mathrm{j}$ & $45.00 \pm 2.9 \mathrm{~h} 1$ & $75.00 \pm 6.4 \mathrm{cf}$ & $80.67 \pm 3.5 \mathrm{ad}$ & $58.92 \pm 6.1 B$ \\
\hline & SL 64 & $67.00 \pm 4.6 \mathrm{efg}$ & $65.00 \pm 4.0 \mathrm{fg}$ & $80.00 \pm 6.4 \mathrm{be}$ & $88.67 \mathrm{ab} \pm 2.9$ & $75.17 \pm 3.5 \mathrm{~A}$ \\
\hline & Average & $46.92 \pm 4.7 D$ & $60.50 \pm 3.2 C$ & $78.33 \pm 3.6 B$ & $87.42 \pm 2.7 A$ & \\
\hline & $\mathrm{CV}(\%)$ & & & 11.91 & & \\
\hline & Genotype & $* *$ & & & 6.77 & \\
\hline & Dose & $* *$ & LSD & & 6.77 & \\
\hline & Genotype x Dose & $* *$ & & & 13.56 & \\
\hline \multirow{9}{*}{ 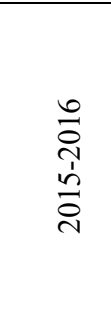 } & $28 \mathrm{M} 005$ & $32.67 \pm 2.4 \mathrm{~g}$ & $61.33 \pm 4.1 \mathrm{de}$ & $69.17 \pm 4.7 \mathrm{~cd}$ & $86.00 \pm 6.8 \mathrm{a}$ & $62.29 \pm 6.2 \mathrm{~B}$ \\
\hline & $52 \mathrm{M} 003$ & $54.67 \pm 0.4 \mathrm{e}$ & $64.83 \pm 1.9 \mathrm{~d}$ & $85.33 \pm 7.9 a$ & $93.33 \pm 2.0 \mathrm{a}$ & $74.54 \pm 5.0 \mathrm{~A}$ \\
\hline & $55 \mathrm{M} 005$ & $35.00 \pm 2.9 \mathrm{fg}$ & $42.50 \pm 0.0 \mathrm{f}$ & $75.00 \pm 4.3 b c$ & $74.50 \pm 2.9 c$ & $56.75 \pm 5.6 \mathrm{C}$ \\
\hline & SL 64 & $66.67 \pm 1.3 \mathrm{~cd}$ & $63.33 \pm 4.1 \mathrm{de}$ & $84.00 \pm 6.0 \mathrm{ab}$ & $91.00 \pm 3.0 \mathrm{a}$ & $76.25 \pm 3.9 \mathrm{~A}$ \\
\hline & Average & $47.25 \pm 4.3 D$ & $58.00 \pm 3.0 C$ & $78.38 \pm 3.2 B$ & $86.21 \pm 2.8 A$ & \\
\hline & $\mathrm{CV}(\%)$ & & & 12.18 & & \\
\hline & Genotype & $* *$ & & & 4.74 & \\
\hline & Dose & $* *$ & LSD & & 4.74 & \\
\hline & Genotype x Dose & $* *$ & & & 9.49 & \\
\hline
\end{tabular}

${ }^{* *}$ Different letters in the same line or column are statistically significant at $p \leq 0.01$. ns: non־significant.

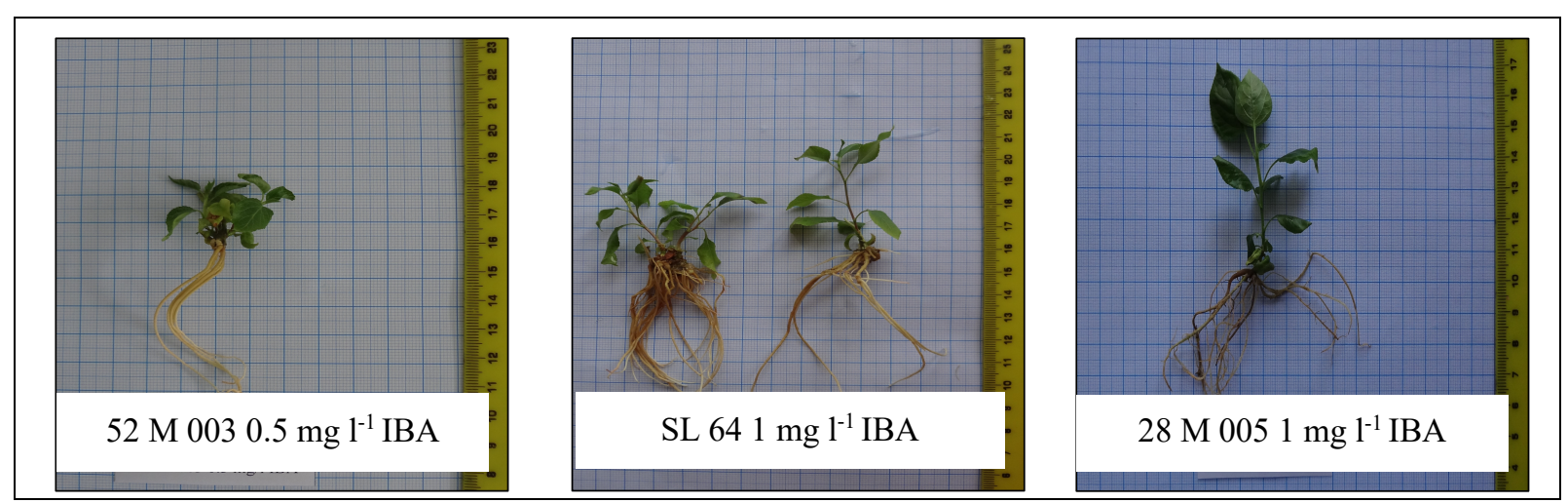

Figure 1. Rooting rate of different IBA concentrations in mahaleb genotypes. 
Table 5. Effect of IBA doses on mahaleb genotypes and SL 64 rootstock of rooting rate (\%) and LSD multiple groupings

\begin{tabular}{|c|c|c|c|c|c|c|}
\hline \multirow[b]{2}{*}{ Year } & \multirow[b]{2}{*}{ Genotype } & \multicolumn{4}{|c|}{ IBA dose } & \multirow[b]{2}{*}{ Average } \\
\hline & & $0 \mathrm{mg} \mathrm{l}^{-1}$ & $0.5 \mathrm{mg} \mathrm{l}^{-1}$ & $1 \mathrm{mg} \mathrm{l}^{-1}$ & $2 \mathrm{mg} \mathrm{l}^{-1}$ & \\
\hline \multirow{9}{*}{2015} & $28 \mathrm{M} 005$ & $0.0 \pm 0.00 \mathrm{~h}$ & $35.00 \pm 2.89 \mathrm{~g}$ & $54.33 \pm 4.70 \mathrm{def}$ & $70.33 \pm 6.01 b c$ & $39.92 \pm 8.10 \mathrm{~B}$ \\
\hline & $52 \mathrm{M} 003$ & $41.00 \pm 2.08 \mathrm{fg}$ & $49.00 \pm 2.08 \mathrm{efg}$ & $66.67 \pm 13.02 \mathrm{bcd}$ & $80.00 \pm 7.64 a b$ & $59.17 \pm 5.63 \mathrm{~A}$ \\
\hline & $55 \mathrm{M} 005$ & $0.0 \pm 0.00 \mathrm{~h}$ & $0.0 \pm 0.00 \mathrm{~h}$ & $56.67 \pm 3.33 \mathrm{cde}$ & $55.00 \pm 2.89 \mathrm{def}$ & $27.92 \pm 8.47 \mathrm{C}$ \\
\hline & SL 64 & $50.00 \pm 5.77 \mathrm{ef}$ & $48.33 \pm 6.01 \mathrm{efg}$ & $71.67 \pm 4.41 b$ & $88.33 \pm 6.01 \mathrm{a}$ & $64.58 \pm 5.52 \mathrm{~A}$ \\
\hline & Average & $22.75 \pm 7.05 D$ & $33.08 \pm 6.18 C$ & $62.33 \pm 3.83 B$ & $73.42 \pm 4.50 \mathrm{~A}$ & \\
\hline & CV (\%) & $* *$ & & 16.84 & & \\
\hline & Genotype & $* *$ & & & 7.45 & \\
\hline & Dose & $* *$ & LSD & & 7.44 & \\
\hline & Genotype x Dose & $* *$ & & & 14.93 & \\
\hline \multirow{8}{*}{2016} & $28 \mathrm{M} 005$ & $0.0 \pm 0.00 \mathrm{e}$ & $50.00 \pm 5.77 \mathrm{~cd}$ & $49.00 \pm 7.00 \mathrm{~cd}$ & $71.00 \pm 7.23 \mathrm{ab}$ & $42.50 \pm 8.24 \mathrm{~B}$ \\
\hline & $52 \mathrm{M} 003$ & $39.67 \pm 2.03 \mathrm{~d}$ & $53.33 \pm 2.73 c$ & $78.33 \pm 6.01 \mathrm{a}$ & $78.33 \pm 4.41 \mathrm{a}$ & $62.42 \pm 5.31 \mathrm{~A}$ \\
\hline & $55 \mathrm{M} 005$ & $0.0 \pm 0.00 \mathrm{e}$ & $0.0 \pm 0.00 \mathrm{e}$ & $66.67 \pm 7.26 \mathrm{ab}$ & $59.33 \pm 0.67 b c$ & $31.50 \pm 9.66 \mathrm{C}$ \\
\hline & SL 64 & $50.00 \pm 2.89 \mathrm{~cd}$ & $52.67 \pm 4.33 c$ & $70.00 \pm 5.77 \mathrm{ab}$ & $75.00 \pm 2.89 a$ & $61.92 \pm 3.70 \mathrm{~A}$ \\
\hline & $\begin{array}{l}\text { Average } \\
\text { CV(\%) }\end{array}$ & $22.42 \pm 6.89 C$ & $39.00 \pm 7.00 B$ & $\begin{array}{c}66.00 \pm 4.26 A \\
12.97\end{array}$ & $70.92 \pm 2.89 A$ & \\
\hline & Genotype & $* *$ & & & 6.48 & \\
\hline & Dose & ** & LSD & & 6.49 & \\
\hline & Genotype $\mathrm{x}$ Dose & ** & & & 14.93 & \\
\hline \multirow{9}{*}{ 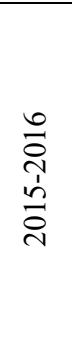 } & $28 \mathrm{M} 005$ & $0.0 \pm 0.00 \mathrm{~h}$ & $42.50 \pm 4.42 \mathrm{fg}$ & $51.67 \pm 3.96 \mathrm{ef}$ & $70.67 \pm 4.21 b c$ & $41.21 \pm 5.65 \mathrm{~B}$ \\
\hline & $52 \mathrm{M} 003$ & $40.33 \pm 1.33 \mathrm{~g}$ & $51.17 \pm 1.82 \mathrm{ef}$ & $72.50 \pm 6.92 \mathrm{ab}$ & $79.17 \pm 3.96 \mathrm{ab}$ & $60.79 \pm 3.80 \mathrm{~A}$ \\
\hline & $55 \mathrm{M} 005$ & $0.0 \pm 0.00 \mathrm{~h}$ & $0.0 \pm 0.00 \mathrm{~h}$ & $61.67 \pm 4.22 \mathrm{~cd}$ & $57.17 \pm 1.64 \mathrm{de}$ & $29.71 \pm 6.29 \mathrm{C}$ \\
\hline & SL 64 & $50.00 \pm 2.89 \mathrm{ef}$ & $50.50 \pm 3.45 \mathrm{ef}$ & $70.83 \pm 3.27 b c$ & $81.67 \pm 4.22 \mathrm{a}$ & $63.25 \pm 3.26 \mathrm{~A}$ \\
\hline & Average & $22.58 \pm 4.82 C D$ & $36.04 \pm 4.6 C$ & $64.17 \pm 2.83 B$ & $72.17 \pm 2.63 A$ & \\
\hline & $\mathrm{CV}(\%)$ & & & 16.80 & & \\
\hline & Genotype & $* *$ & & & 4.72 & \\
\hline & Dose & $* *$ & LSD & & 4.72 & \\
\hline & Genotype x Dose & $* *$ & & & 9.45 & \\
\hline
\end{tabular}

** Different letters in the same line or column are statistically significant at $p \leq 0.01$.

Table 6. Effect of IBA doses on mahaleb genotypes and SL 64 rootstock of root length (mm) and LSD multiple groupings

\begin{tabular}{|c|c|c|c|c|c|c|}
\hline \multirow{2}{*}{ Year } & \multirow{2}{*}{ Genotype } & \multicolumn{4}{|c|}{ IBA dose } & \multirow{2}{*}{ Average } \\
\hline & & $0 \mathrm{mg} \mathrm{l}^{-1}$ & $0.5 \mathrm{mg} \mathrm{l}^{-1}$ & $1 \mathrm{mg} \mathrm{l}^{-1}$ & $2 \mathrm{mg} \mathrm{l}^{-1}$ & \\
\hline \multirow{8}{*}{2015} & $28 \mathrm{M} 005$ & $0.0 \pm 0.00 \mathrm{j}$ & $48.04 \pm 1.17 b$ & $38.02 \pm 0.42 \mathrm{~d}$ & $25.06 \pm 1.97 \mathrm{~g}$ & $27.78 \pm 5.45 \mathrm{~B}$ \\
\hline & $52 \mathrm{M} 003$ & $25.63 \pm 0.89 \mathrm{fg}$ & $54.21 \pm 0.93 a$ & $42.27 \pm 0.45 c$ & $47.38 \pm 0.59 b$ & $42.37 \pm 3.20 \mathrm{~A}$ \\
\hline & $55 \mathrm{M} 005$ & $0.0 \pm 0.00 \mathrm{j}$ & $0.0 \pm 0.00 \mathrm{j}$ & $7.62 \pm 0.411$ & $35.26 \pm 1.79 \mathrm{e}$ & $10.72 \pm 4.39 \mathrm{D}$ \\
\hline & SL 64 & $15.41 \pm 0.71 \mathrm{~h}$ & $13.15 \pm 0.31 \mathrm{~h}$ & $27.96 \pm 0.93 f$ & $24.63 \pm 0.76 \mathrm{~g}$ & $20.29 \pm 1.88 \mathrm{C}$ \\
\hline & $\begin{array}{l}\text { Average } \\
\text { CV }(\%)\end{array}$ & $10.26 \pm 3.29 C$ & $28.85 \pm 6.90 B$ & $\begin{array}{c}28.97 \pm 4.04 B \\
6.08\end{array}$ & $33.08 \pm 2.86 A$ & \\
\hline & Genotype & $* *$ & & & 1.29 & \\
\hline & Dose & $* *$ & LSD & & 1.29 & \\
\hline & Genotype x Dose & $* *$ & & & 2.57 & \\
\hline \multirow{8}{*}{2016} & $28 \mathrm{M} 005$ & $0.0 \pm 0.00 \mathrm{j}$ & $44.17 \pm 0.85 b$ & $36.63 \pm 1.28 \mathrm{~d}$ & $24.80 \pm 0.93 f$ & $26.40 \pm 5.06 \mathrm{~B}$ \\
\hline & $52 \mathrm{M} 003$ & $26.85 \pm 1.06 f$ & $46.16 \pm 1.86 \mathrm{~b}$ & $39.66 \pm 0.44 c$ & $51.40 \pm 0.36 \mathrm{a}$ & $41.02 \pm 2.81 \mathrm{~A}$ \\
\hline & $55 \mathrm{M} 005$ & $0.0 \pm 0.00 \mathrm{j}$ & $0.0 \pm 0.00 \mathrm{j}$ & $10.28 \pm 0.311$ & $34.83 \pm 1.13 \mathrm{~d}$ & $11.28 \pm 4.30 \mathrm{D}$ \\
\hline & SL 64 & $14.72 \pm 0.29 \mathrm{~h}$ & $12.80 \pm 0.25 h$ & $31.09 \pm 0.17 \mathrm{e}$ & $21.37 \pm 0.59 \mathrm{~g}$ & $19.20 \pm 2.16 \mathrm{C}$ \\
\hline & $\begin{array}{l}\text { Average } \\
\text { CV }(\%)\end{array}$ & $10.39 \pm 3.40 D$ & $25.78 \pm 6.02 C$ & $\begin{array}{c}29.41 \pm 3.47 B \\
5.55\end{array}$ & $33.10 \pm 3.53 A$ & \\
\hline & Genotype & $* *$ & & & 1.14 & \\
\hline & Dose & $* *$ & LSD & & 1.14 & \\
\hline & Genotype x Dose & $* *$ & & & 2.28 & \\
\hline \multirow{8}{*}{ 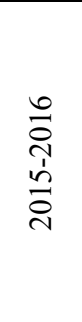 } & $28 \mathrm{M} 005$ & $0.0 \pm 0.001$ & $46.11 \pm 1.08 \mathrm{~b}$ & $37.33 \pm 0.68 d$ & $24.93 \pm 0.98 g$ & $27.09 \pm 3.64 \mathrm{~B}$ \\
\hline & $52 \mathrm{M} 003$ & $26.24 \pm 0.68 \mathrm{~g}$ & $50.19 \pm 2.02 \mathrm{a}$ & $40.96 \pm 0.65 c$ & $49.39 \pm 0.95 a$ & $41.69 \pm 2.08 \mathrm{~A}$ \\
\hline & $55 \mathrm{M} 005$ & $0.0 \pm 0.001$ & $0.0 \pm 0.001$ & $8.95 \pm 0.64 \mathrm{k}$ & $35.05 \pm 0.95 \mathrm{e}$ & $11.00 \pm 3.00 \mathrm{D}$ \\
\hline & SL 64 & $15.07 \pm 0.381$ & $12.98 \pm 0.19 \mathrm{j}$ & $29.53 \pm 0.82 f$ & $23.00 \pm 0.85 \mathrm{~h}$ & $20.14 \pm 1.40 \mathrm{C}$ \\
\hline & $\begin{array}{l}\text { Average } \\
\mathrm{CV}(\%)\end{array}$ & $10.33 \pm 2.31 D$ & $27.32 \pm 4.49 C$ & $\begin{array}{c}29.19 \pm 2.60 B \\
5.92\end{array}$ & $33.09 \pm 2.22 A$ & \\
\hline & Genotype & $* *$ & & & 0.85 & \\
\hline & Dose & $* *$ & LSD & & 0.85 & \\
\hline & Genotype x Dose & $* *$ & & & 1.71 & \\
\hline
\end{tabular}

\footnotetext{
${ }^{* *}$ Different letters in the same line or column are statistically significant at $p \leq 0.01$.
} 
Table 7. The effect of IBA doses on mahaleb genotypes and SL 64 rootstock of rooted plant length (mm) and LSD multiple groupings

\begin{tabular}{|c|c|c|c|c|c|c|}
\hline \multirow{2}{*}{ Year } & \multirow{2}{*}{ Genotype } & \multicolumn{4}{|c|}{ IBA dose } & \multirow{2}{*}{ Average } \\
\hline & & $0 \mathrm{mg} \mathrm{l}^{-1}$ & $0.5 \mathrm{mg}^{-1}$ & $1 \mathrm{mg}^{-1}$ & $2 \mathrm{mg}^{-1}$ & \\
\hline \multirow{8}{*}{2015} & $28 \mathrm{M} 005$ & $0.0 \pm 0.00 \mathrm{i}$ & $15.35 \pm 0.37 \mathrm{de}$ & $34.76 \pm 1.19 a$ & $8.98 \pm 0.141$ & $14.77 \pm 3.86 \mathrm{~B}$ \\
\hline & $52 \mathrm{M} 003$ & $12.95 \pm 0.62 \mathrm{efg}$ & $16.54 \pm 1.04 \mathrm{~d}$ & $23.52 \pm 1.43 \mathrm{c}$ & $10.71 \pm 0.51 \mathrm{gh} 1$ & $15.93 \pm 1.52 \mathrm{~B}$ \\
\hline & $55 \mathrm{M} 005$ & $0.0 \pm 0.00 \mathrm{i}$ & $0.0 \pm 0.00 \mathrm{i}$ & $10.34 \pm 0.46 h_{1}$ & $13.20 \pm 0.73 \mathrm{ef}$ & $5.89 \pm 1.81 \mathrm{C}$ \\
\hline & SL 64 & $11.75 \pm 0.43 \mathrm{fgh}$ & $13.99 \pm 0.40 \mathrm{ef}$ & $35.01 \pm 1.71 \mathrm{a}$ & $28.13 \pm 1.14 b$ & $22.22 \pm 2.96 \mathrm{~A}$ \\
\hline & $\begin{array}{l}\text { Average } \\
\mathrm{CV}(\%)\end{array}$ & $6.17 \pm 1.87 D$ & $11.47 \pm 2.03 C$ & $\begin{array}{c}25.91 \pm 3.10 A \\
9.93\end{array}$ & $15.25 \pm 2.31 B$ & \\
\hline & Genotype & $* *$ & & & 1.22 & \\
\hline & Dose & $* *$ & LSD & & 1.20 & \\
\hline & Genotype $\mathrm{x}$ Dose & $* *$ & & & 2.43 & \\
\hline \multirow{8}{*}{2016} & $28 \mathrm{M} 005$ & $0.0 \pm 0.00 \mathrm{~h}$ & $17.99 \pm 0.63 \mathrm{e}$ & $36.69 \pm 1.07 \mathrm{a}$ & $10.75 \pm 034 \mathrm{~g}$ & $16.36 \pm 4.04 \mathrm{C}$ \\
\hline & $52 \mathrm{M} 003$ & $15.47 \pm 0.60 f$ & $20.12 \pm 0.83 \mathrm{~d}$ & $26.00 \pm 0.50 b$ & $13.85 \pm 0.85 \mathrm{f}$ & $18.86 \pm 1.46 \mathrm{~B}$ \\
\hline & $55 \mathrm{M} 005$ & $0.0 \pm 0.00 \mathrm{~h}$ & $0.0 \pm 0.00 \mathrm{~h}$ & $11.20 \pm 0.49 \mathrm{~g}$ & $10.37 \pm 0.67 \mathrm{~g}$ & $5.39 \pm 1.64 \mathrm{D}$ \\
\hline & SL 64 & $10.97 \pm 0.19 \mathrm{~g}$ & $17.45 \pm 0.49 \mathrm{e}$ & $35.63 \pm 0.37 \mathrm{a}$ & $24.01 \pm 0.86 \mathrm{c}$ & $22.02 \pm 2.76 \mathrm{~A}$ \\
\hline & $\begin{array}{l}\text { Average } \\
\mathrm{CV}(\%)\end{array}$ & $6.61 \pm 2.05 D$ & $13.89 \pm 2.45 C$ & $\begin{array}{c}27.38 \pm 3.10 A \\
6.51\end{array}$ & $14.75 \pm 1.69 B$ & \\
\hline & Genotype & ** & & & 0.86 & \\
\hline & Dose & $* *$ & LSD & & 0.86 & \\
\hline & Genotype x Dose & $* *$ & & & 1.69 & \\
\hline \multirow{8}{*}{ 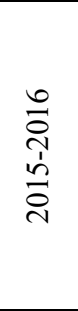 } & $28 \mathrm{M} 005$ & $0.0 \pm 0.001$ & $16.67 \pm 0.67 \mathrm{~d}$ & $35.73 \pm 0.84 a$ & $9.87 \pm .0 .43 \mathrm{~h}$ & $15.57 \pm 2.74 \mathrm{C}$ \\
\hline & $52 \mathrm{M} 003$ & $15.47 \pm 0.68 f$ & $18.33 \pm 1.00 \mathrm{c}$ & $24.76 \pm 0.88 b$ & $12.28 \pm 0.83 f$ & $17.40 \pm 1.07 \mathrm{~B}$ \\
\hline & $55 \mathrm{M} 005$ & $0.0 \pm 0.001$ & $0.0 \pm 0.001$ & $10.77 \pm 0.36 \mathrm{gh}$ & $11.79 \pm 0.77 \mathrm{fg}$ & $5.64 \pm 1.19 \mathrm{D}$ \\
\hline & SL 64 & $11.36 \pm 0.27 \mathrm{fg}$ & $15.72 \pm 0.82 \mathrm{~d}$ & $35.32 \pm 0.79 a$ & $26.07 \pm 1.12 b$ & $22.12 \pm 1.98 \mathrm{~A}$ \\
\hline & Average & $6.39 \pm 1.36 D$ & $12.68 \pm 1.58 C$ & $26.64 \pm 2.18 A$ & $15.00 \pm 1.40 B$ & \\
\hline & $\begin{array}{c}\mathrm{CV}(\%) \\
\text { Genotyne }\end{array}$ & & & 8.30 & & \\
\hline & $\begin{array}{c}\text { Genotype } \\
\text { Dose }\end{array}$ & $\begin{array}{l}* * \\
* *\end{array}$ & SD & & 0.73 & \\
\hline & $\begin{array}{l}\text { Dose } \\
\text { Genotype } \mathrm{x} \text { Dose }\end{array}$ & $* *$ & LSD & & $\begin{array}{l}0.73 \\
1.46\end{array}$ & \\
\hline
\end{tabular}

** Different letters in the same line or column are statistically significant at $p \leq 0.01$.

Table 8. Effect of IBA doses on mahaleb genotypes and SL 64 rootstock of number of leaves and LSD multiple groupings

\begin{tabular}{|c|c|c|c|c|c|c|}
\hline \multirow{2}{*}{ Year } & \multirow{2}{*}{ Genotype } & \multicolumn{4}{|c|}{ IBA dose } & \multirow{2}{*}{ Average } \\
\hline & & $0 \mathrm{mg} \mathrm{l}^{-1}$ & $0.5 \mathrm{mg} \mathrm{l}^{-1}$ & $1 \mathrm{mg} \mathrm{l}^{-1}$ & $2 \mathrm{mg} \mathrm{l}^{-1}$ & \\
\hline \multirow{8}{*}{2015} & $28 \mathrm{M} 005$ & $0.0 \pm 0.00 \mathrm{f}$ & $6.47 \pm 0.36 \mathrm{~d}$ & $7.17 \pm 0.48 \mathrm{~cd}$ & $5.10 \pm 0.24 \mathrm{e}$ & $4.68 \pm 0.86 \mathrm{~B}$ \\
\hline & $52 \mathrm{M} 003$ & $7.71 \pm 0.40 \mathrm{bc}$ & $7.16 \pm 0.39 \mathrm{~cd}$ & $8.35 \pm 0.56 \mathrm{ab}$ & $6.91 \pm 0.23 \mathrm{~cd}$ & $7.53 \pm 0.24 \mathrm{~A}$ \\
\hline & $55 \mathrm{M} 005$ & $0.0 \pm 0.00 f$ & $0.0 \pm 0.00 f$ & $5.19 \pm 0.19 \mathrm{e}$ & $8.87 \pm 0.83 \mathrm{a}$ & $3.51 \pm 1.14 \mathrm{C}$ \\
\hline & SL 64 & $6.33 \pm 0.57 d$ & $6.86 \pm 0.25 \mathrm{~cd}$ & $8.99 \pm 0.12 \mathrm{a}$ & $6.81 \pm 0.29 \mathrm{~cd}$ & $7.25 \pm 0.34 \mathrm{~B}$ \\
\hline & $\begin{array}{l}\text { Average } \\
\text { CV }(\%)\end{array}$ & $3.51 \pm 1.08 C$ & $5.12 \pm 0.90 B$ & $\begin{array}{c}7.42 \pm 0.47 A \\
11.84\end{array}$ & $6.92 \pm 0.45 A$ & \\
\hline & Genotype & $* *$ & & & 0.56 & \\
\hline & Dose & $* *$ & LSD & & 0.56 & \\
\hline & Genotype x Dose & $* *$ & & & 1.14 & \\
\hline \multirow{8}{*}{2016} & $28 \mathrm{M} 005$ & $0.0 \pm 0.00 \mathrm{~h}$ & $6.03 \pm 0.06 \mathrm{fg}$ & $6.85 \pm 0.27 \mathrm{de}$ & $5.84 \pm 0.12 \mathrm{fg}$ & $4.68 \pm 0.82 C$ \\
\hline & $52 \mathrm{M} 003$ & $7.6 \pm 0.221 \mathrm{c}$ & $8.56 \pm 0.26 a$ & $7.82 \pm 0.37 b c$ & $6.30 \pm 0.17 \mathrm{ef}$ & $7.57 \pm 0.27 \mathrm{~A}$ \\
\hline & $55 \mathrm{M} 005$ & $0.0 \pm 0.00 \mathrm{~h}$ & $0.0 \pm 0.00 \mathrm{~h}$ & $6.71 \pm 0.24 \mathrm{de}$ & $7.28 \pm 0.25 \mathrm{~cd}$ & $3.50 \pm 1.06 \mathrm{D}$ \\
\hline & SL 64 & $7.23 \pm 0.14 \mathrm{~cd}$ & $5.65 \pm 0.31 \mathrm{~g}$ & $8.35 \pm 0.33 \mathrm{ab}$ & $6.76 \pm 0.20 \mathrm{de}$ & $7.00 \pm 0.31 B$ \\
\hline & $\begin{array}{l}\text { Average } \\
\text { CV }(\%)\end{array}$ & $3.71 \pm 1.12 D$ & $5.06 \pm 0.95 C$ & $\begin{array}{c}7.44 \pm 0.24 A \\
6.68\end{array}$ & $6.54 \pm 0.18 B$ & \\
\hline & Genotype & $* *$ & & & 0.30 & \\
\hline & Dose & $* *$ & LSD & & 0.30 & \\
\hline & Genotype x Dose & $* *$ & & & 0.63 & \\
\hline \multirow{8}{*}{ 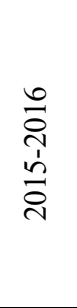 } & $28 \mathrm{M} 005$ & $0.0 \pm 0.00 \mathrm{~g}$ & $6.25 \pm 0.19 \mathrm{de}$ & $7.01 \pm 0.26 \mathrm{c}$ & $5.47 \pm 0.21 \mathrm{f}$ & $4.68 \pm 0.58 \mathrm{C}$ \\
\hline & $52 \mathrm{M} 003$ & $7.66 \pm 0.20 b$ & $7.86 \pm 0.38 b$ & $8.09 \pm 0.32 \mathrm{ab}$ & $6.61 \pm 0.19 \mathrm{~cd}$ & $7.55 \pm 0.18 \mathrm{~A}$ \\
\hline & $55 \mathrm{M} 005$ & $0.0 \pm 0.00 \mathrm{~g}$ & $0.0 \pm 0.00 \mathrm{~g}$ & $5.95 \pm 0.37 \mathrm{ef}$ & $8.08 \pm 0.53 \mathrm{ab}$ & $3.51 \pm 0.76 \mathrm{D}$ \\
\hline & SL 64 & $6.78 \pm 0.33 \mathrm{~cd}$ & $6.26 \pm 0.32 \mathrm{de}$ & $8.67 \pm 0.21 \mathrm{a}$ & $6.79 \pm 0.16 \mathrm{~cd}$ & $7.12 \pm 0.23 B$ \\
\hline & $\begin{array}{l}\text { Average } \\
\text { CV }(\%)\end{array}$ & $3.61 \pm 0.76 D$ & $5.09 \pm 0.64 C$ & $\begin{array}{c}7.43 \pm 0.26 A \\
9.62\end{array}$ & $6.73 \pm 0.24 B$ & \\
\hline & Genotype & $* *$ & & & 0.32 & \\
\hline & Dose & $* *$ & LSD & & 0.32 & \\
\hline & Genotvpe $x$ Dose & $* *$ & & & 0.63 & \\
\hline
\end{tabular}

\footnotetext{
${ }^{* *}$ Different letters in the same line or column are statistically significant at $p \leq 0.01$.
} 


\section{Discussion and Conclusion}

The study was carried out to determine the candidate mahaleb genotypes for cherry of different BAP and IBA doses and the replication performances of SL 64 rootstock. According to the average of years, the infected culture rate of mahaleb genotypes and SL 64 rootstocks was determined to be between $18.57 \%$ (SL 64) and 29.07\% (55 M 005) (Table 2). In the studies conducted, the rate of infected cultures (Hepaksoy, 2004) reported that it was between 35.0-45.0\%, (Boşnjakovic et al., 2013) between 40-86\%, (Aydın et al., 2016) between 22.0-47.0\% and (Sanyürek et al., 2021) between 20-35\%. The results obtained from the study are lower than the results of other studies. This difference may be due to the sterilization method used in the study.

The number of shoots is 1.97 (28 M 005) -2.55 (52 M 003) The results we obtained from the experiment are similar with the findings of (Kitin et al., 2005; Srinivasan et al., 2005 and Durkovic, 2006; Güçlü et al., 2010) who reported that BAP is the most commonly used cytokine for shoot propagation in Prunus species and that the maximum number of shoots is obtained at a dose of 1 $\mathrm{mg}^{-1}$.

Callus rate of mahaleb genotypes and SL 64 rootstocks was determined to be between $56.75 \%$ and $76.25 \%$. The results we obtained from the trial are consistent with the results of Sülüşoğlu (2002), Sülüşoğlu and Çavuşoğlu (2013), and Hosseinpour et al., (2015) who reported that the use of IBA as auxin in the propagation positively affected the formation of callus rate.

The rooting rate is $29.71 \%$ (It ranged from $55 \mathrm{M} 005$ ) to $63.25 \%$ (SL 64) In the studies conducted, they found the rooting rate as (Hepaksoy, 2004) 33.33-66.66\%; (Canl1 and Demir, 2014) 20.0-70\%; (Aydın et al., 2016) 34.83-71.13\% and (Pakyürek and Hepaksoy, 2019) 20.0-73.0\%; The findings we obtained from the trial are similar to those of previous studies.

According to the average of years, root length was determined to be between $11.00 \mathrm{~mm}$ and $41.69 \mathrm{~mm}$. In in vitro replication studies of the Prunus species, the root length reported as (Sülüsoğlu and Çavuşoğlu, 2013) 1.68-3.29 cm; (Hosseinpour et al., 2015) 1- $2.03 \mathrm{~cm}$ and (Fallahpour et al., 2015) $1.5-3.1 \mathrm{~cm}$. The results we obtained from the trial are in agreement with the results of the studies on this subject.

Rooted plant length of mahaleb genotypes and SL 64 rootstocks was determined to be between $5.64 \mathrm{~mm}$ and $22.12 \mathrm{~mm}$. In previous studies on the subject, the length of rooted plants (Sülüşoğlu and Çavuşoğlu, 2013) 1.27-2.15 cm; (Doric et al., 2014) reported 4.4-12.7 cm and (Sharma et al., 2017) reported 4-6 cm. Our results are in agreement with the results of the studies on this subject.

The highest number of leaves was obtained from $52 \mathrm{M} 003$ genotypes with 7.55 pieces. The results we obtained from the trial are consistent with the results of (Aktürk, 2009) and (Shabani et al., 2015) who reported that the use of IBA as auxin in the propagation studies of Prunus species in vitro positively affected the formation of new leaves.

In the study, the increase of BAP dose increased the number of shoots of mahaleb genotypes and SL 64 rootstock. While the highest value in terms of rooting rate and root length was obtained from $2 \mathrm{mg}^{-1}$ IBA dose, the highest value in terms of rooted plant length and number of leaves was obtained from $1 \mathrm{mg}{ }^{-1}$ IBA dose. If we evaluate the genotypes in terms of their propagation performance, The 52 M 003 genotype takes first place.

\section{Acknowledgment}

This research was funded by the Scientific Research Projects Coordination Unit of Ordu University, Turkey (Project Number TF 1506).

\section{References}

Aka-Kaçar, Y., Yılmaz, N., Yalçın-Mendi, Y., Küden, A., \& Çetiner, S. (2001). Effects of different solidifying agents and different $p H$ levels used in in vitro media on growth of some cherry (Prunus avium L.) rootstocks. I. Stone Seed Fruit Symposium., Yalova.

Aktürk, Z. (2009). In vitro micropropagation of cherry (Prunus avium L.). (PhD), Dicle University, Institute of Natural and Applied Sciences Diyarbakır, Turkey. 
Aydın, E., Varol, İ., Demirsoy, L., Demirsoy, H., \& Er, E. (2016). Production of Gisela 5, Gisela 6 and SL 64 rootstocks in different media. Yalova Atatürk Horticultural Research Institute Journal, 45/1, 487-491.

Bilginer, Ş., Ercişli, S., Gerçekcioğlu, R., Eşitgen, A., Güneş, M., Akbulut, M., Koç, A., \& Çelik, T.Z. (2009). Cherry Rootstock Selectıon Breeding In Central and Eastern Black Sea Region. Samsun, Turkey: The Scientific and Technological Research Council of Turkey- Agriculture, Forestry and Veterinary Research Grant Committee- Project Final Report Number 106O031.

Borkowska, B., \& Szczerba, J.(1991). Influence of different carbon sources on invertase activity and growth of sour cherry (Prunus cerasus L.) shoot cultures. J. of Exp. Botany 240 (42), 911-915.

Bosnjakovic, D., Ognjanov, V., Barac, G., Ljubojevic., M, Pranjic, A., \& Dugalic, K. (2013). Micropropagation of low-vigorous rootstock selections for sweet and sour cherry. Voc arstvo $47(183 / 184), 121-128$.

Canli, F. A., \& Demir, F. (2014). In vitro multiplication and rooting of 'F12-1'(Prunus avium L.) and 'Maxma 14'(P. mahaleb L. $\times$ P. avium L.) rootstocks. Indian Journal of Horticulture, 71(2), 145150.

Doriç, D., Ognjanov, V., Ljubojeviç, M., Baraç, G., Duliç, J., Pranjiç, A., \& Dugaliç, K. (2014). Rapid propagation of sweet and sour cherry rootstocks. Notulae Botanicae Horti Agrobotanici ClujNapoca, 42(2), 488-494.

Durkoviç, J. (2006). Rapid mikropropagation of mature wild cherry. Biologia Plantarum, 50 (4), 733 736.

Ercişli, S., Eşitken, A., Orhan, E., \& Özdemir, O. (2006). Rootstocks used for temperate fruit trees in Turkey: an overview. scientific works of the Lithuanian Institute of Horticulture and Lithuanian University of Agriculture. Sodininkyste Ir Darzininkyste, 25(3): 27-33.

Fallahpour, M., Miri, S. M., \& Bouzari, N. (2015). In vitro propagation of Gisela 5 rootstock as affected by mineral composition of media and plant growth regulators. Journal of Horticultural Research, 23(1), 57-64.

Güçlü, F,. Fatma, K., \& Şan B. (2010). The in vitro micropropagation of some clonal cherry rootstocks. Journal of Natural and Applied Sciences, 14.(2), 144-147.

Hepaksoy, S. (2004). Researchs on micropropagation of some cherry rootstocks. Ege University, Journal of Agricultural Faculty, 41(3), 11-22.

Hosseinpour, B., Bouzari, N., Didar, Z., Masoumian, M., Ghaemmaghami, S. A., Ebrahimi, A., \& Farvardin, A. (2015). High frequency in vitro propagation of MxM 60, a cherry rootstock: the effects of culture media and growth regulators. Iranian Journal of Genetics and Plant Breeding, 4(2), 28-36.

Kitin, P., Iliev I., Scaltsoyiannes A., Nellas C., Rubos A., \& Funada R. A. (2005). Comparative histological study between normal and fasciated shoots of Prunus avium generated in vitro. Plant Cell, Tissue and Organ Culture, 82, 141-150.

Koç, A. (2009). A Research on cherry rootstock selectıon and their vegetative propagation potential in Samsun province. (PhD), Ondokuz Mayis University, Institute of Natural and Applied Sciences Samsun, Turkey.

Meraler S. A. (2010). Determination of mineral composition in different plant parts of mahaleb cherry (Prunus mahaleb L.). (Msc) Kilis 7 Aralık University Institute of Natural and Applied Sciences Kilis, Turkey.

Morini, S., Sciutti, R., \& Fortuna, P. (1992). In vitro growth response of Prunus cerasifera shoots as influenced by different light-dark cycles and sucrose concentrations. Plant Cell, Tissue and Organ Culture, 28 (3), 245-248.

Özçağıran, R., Ünal, A., Özeker, E., \& İsfendiyaroğlu, M. (2005). Temparate climate fruits, stone fruits vol. 1. Ege University, Journal of Agricultural Faculty 553, İzmir.

Özyurt, İ. K., \& Akça, Y. (2017). Effects of water stress on biochemical changes of mahaleb (Prunus mahaleb L.) rootstocks. Journal of Agricultural Faculty of Gaziosmanpasa University, 34 (3), 110.

Pakyürek, M. \& Hepaksoy, S. (2019). In vitro propagation of Weiroot 158. Ejons International Journal On Mathematics, Engineering \& Natural Sciences 108-118. 
Sanyürek, N.K., Çakır, A., \& Söylemezoğlu, G. (2021). Optimization of Meristem Culture to Obtain Virus-Free Clonal Basic Material of Grape Cultivars. Yuzuncu Yil University Journal of Agricultural Sciences, 31(3), 617-628.

Shabani, Z., Moghadam, E. G., Abedi, B., \& Tehranifar, A. (2015). The effect of plant growth regulators and their concentration in vitro on mass poropagation of Myrobalan 29C rootstock. Journal of Horticulture and Forestry, 7(3), 57-64.

Sharma, V., Thakur, M., \& Kumar, A. (2017). An efficient method for in vitro propagation of Gisela 5 (Prunus cerasus x Prunus canescens)-clonal cherry rootstock. International Journal of Current Microbiology and Applied Sciences, 6 (8), 2617-2624.

Skirvin, R.M. (1984). Stone Fruits. In P.V. Ammirato, D.A. Evans, W.R. Sharp \& Y. Yamado (Eds), Handbook of Plant Cell Culture, Newyork, USA: Mc. Millan Publishing Company.

Skirvin, R.M., \& Chu, M.C. (1979). In vitro propagation of "Forever Yours" rose. Hort. Science 15 (4), 608-610.

Srinivasan, C., Isabel, M.G., \& Scorza, R. (2005). Prunus spp. almond, apricot, cherry, nectarine, peach and plum. In R. E. Litz (Eds), Biotechnology of fruit and nut crops (pp 512-542). Wallingford, UK: CABI Publishing.

Sülüşoğlu, M. (2002). In vitro propagation of cherry rootstocks. (PhD) Ankara University, Institute of Natural and Applied Sciences Ankara, Turkey.

Sülüşoğlu, M., \& Çavuşoğlu, A.(2013). Micropropagation of cherry laurel Prunus laurocerasus L. Journal of Food, Agriculture and Environment, 11(1), 576-579.

Whiting M D, Lang G, \& Opharth, D. (2005). Rootstocks and training system effect sweet cherry growth yield and fruit quality. Hort. Science, 40(3), 582-586.

Yıldırım, H. (2006). In vitro micropropagation of Hacıhaliloğlu (Prunus armenica L.) variety. (PhD), Dicle University, Institute of Natural and Applied Sciences Diyarbakır, Turkey. 